\title{
Episodic headache due to ruptured intracranial dermoid cyst
}

\author{
Celal Şalçini, ${ }^{1}$ Deniz Hatıloğlu, ${ }^{2}$ Alper Evrensel, ${ }^{3}$ Ali Oğuz Tanrıdağ ${ }^{4}$
}

${ }^{1}$ Department of Neurology, Uskudar University, NPIstanbul Neuropsychiatry Hospital, Istanbul, Turkey

2Department of Radiology, Uskudar University, NPIstanbul Neuropsychiatry Hospital, Istanbul, Turkey ${ }^{3}$ Department of Psychiatry, Uskudar University, İstanbul, Turkey

${ }^{4}$ Department of Neurology, Uskudar University, İstanbul, Turkey

\section{Correspondence to} Dr Alper Evrensel, alperevrensel@gmail.com

Accepted 11 May 2015
CrossMark

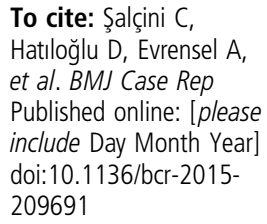

\section{DESCRIPTION}

A 24-year-man presented to the neurology department with sudden onset headache. No neurological deficits, signs of raised intracranial tension or meningeal irritation were found. Also, no medication was started prior to the headache. The patient had experienced similar episodes of headaches for the past 3 years, which were not relieved with analgaesics. The headaches started suddenly from the cervico-occipital region, spreading bilaterally to anterior regions. The attacks were characterised by a dull aching and were episodic, with variable duration between 1 and 2 weeks; they were causing the patient severe disability.

A cranial MRI showed a well-defined, ellipsoid, extra-axial $30 \times 18 \times 11 \mathrm{~mm}$ mass in the anterior neighbour of left MCA, predominantly hyperintense with hypointense heterogenic areas on T1, $\mathrm{T} 2$ and fluid attenuation inversion recovery sequences (figure $1 \mathrm{~A}-\mathrm{C}$ ). The signal was suppressed on fat saturated T1 sequences, confirming the fatty nature of the mass and favouring a dermoid cyst (figure 1D). Additionally, hyperintense signals were seen in the anterior horn of the lateral ventricle (figure 2A) and in the sulcal spaces, especially more on the side of the dermoid cyst, suggesting spilled sebum or greasy grumous material desquamated from the dermoid cyst into the subarachnoid and intraventricular region (figure 2B). A cranial MRI taken at the time of a previous headache episode showed different localisation of fat droplets, no longer visible in the latest cranial MRI, suggesting the possibility of the fat droplets having moved in the subarachnoid space or recurrent leaking material from the cyst causing the headaches (figure 2C).

Intracranial dermoid cysts are rare, benign and slow growing intracranial tumours that occur as a developmental anomaly from trapped ectodermal cells at the time of neural tube closure between the third and fifth week of embryonic life. ${ }^{1}$ Intracranial dermoid cysts are usually asymptomatic and diagnosed incidentally. ${ }^{2}$ Symptomatic presentation occurs by the mass effect or due to spontaneous/ traumatic/iatrogenic rupture. ${ }^{2}$ Rupture can result as chemical meningitis, headache, non-communicating hydrocephalus or vasospasm or even death. Treatments include surgery in symptomatic patients and patients with larger mass, or radiological follow-up in asymptomatic cases. ${ }^{2}$ Our patient was referred to the neurosurgery clinic but did not give consent for surgery, so the diagnosis was performed on clinical and radiological grounds alone.

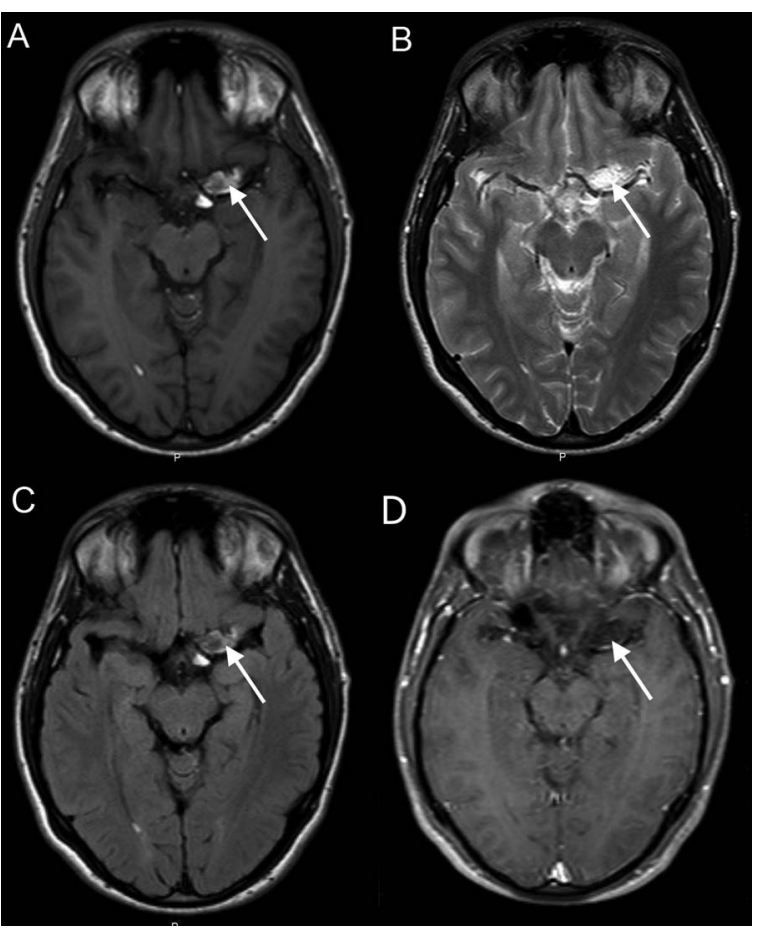

Figure 1 (A) Axial T1-weighted, (B) T2-weighted and (C) fluid attenuation inversion recovery sequences showing well-defined, ellipsoid, extra-axial mass predominantly hyperintense with hypointense heterogenic areas. (D) Fat suppressed T1-weighted image shows suppression on signal intensity compatible with a fat containing lesion. 
Figure 2 (A) T1-weighted image shows hyperintense signals due to subarachnoid fat dissemination in anterior horn of left lateral ventricle and (B) in the sulcal spaces bilaterally. (C) T1-weighted image shows bilateral hyperintense signal in anterior horn of lateral ventricles.

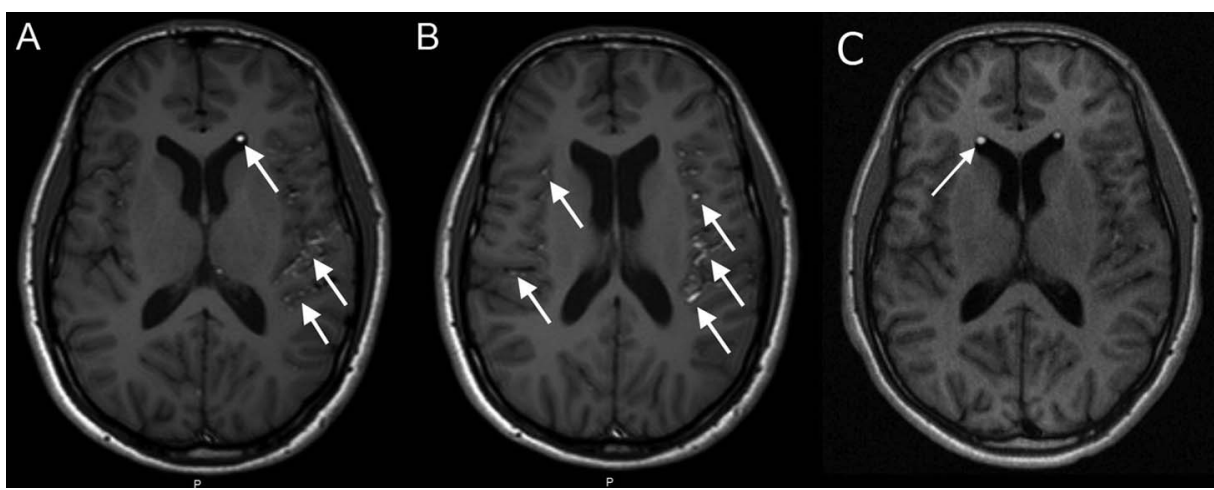

Contributors CS wrote the case history and discussion. DH and AOT assisted with writing the case history. AE reviewed the manuscript.

Competing interests None declared.

Patient consent Obtained.

Provenance and peer review Not commissioned; externally peer reviewed. effect or rupture.

- Rupture of the cyst can manifest as episodic headaches without inflammation or other neurological signs.

- Neuroimaging is suggested in all patients with atypical headaches, and especially in those with episodic headaches.

- Surgery is recommended in larger mass lesions or in symptomatic patients. Asymptomatic cases can be radiologically followed-up.

Copyright 2015 BMJ Publishing Group. All rights reserved. For permission to reuse any of this content visit http://group.bmi.com/group/rights-licensing/permissions.

BMJ Case Report Fellows may re-use this article for personal use and teaching without any further permission.

Become a Fellow of BMJ Case Reports today and you can:

- Submit as many cases as you like

- Enjoy fast sympathetic peer review and rapid publication of accepted articles

- Access all the published articles

- Re-use any of the published material for personal use and teaching without further permission

For information on Institutional Fellowships contact consortiasales@bmjgroup.com

Visit casereports.bmj.com for more articles like this and to become a Fellow 